\title{
A systematic review and narrative summary of family-based smoking cessation interventions to help adults quit smoking
}

\author{
Gill Hubbard ${ }^{1 *}$, Trish Gorely ${ }^{1}$ Gozde Ozakinci ${ }^{2}$, Rob Polson ${ }^{3}$ and Liz Forbat ${ }^{4}$
}

\begin{abstract}
Background: Smoking is the most significant preventable cause of morbidity and early mortality in the world. The family is an influential context in which smoking behaviour occurs.

Methods: A systematic review and narrative summary of family-based interventions to help adults quit smoking was conducted.

Results: Eight controlled trials were included. Risk of bias was high. The smoking-related outcome of the intervention was self-reported smoking status/abstinence, validated by objective measures (including saliva thiocynate or breath carbon monoxide). Follow-up ranged from 6 weeks to 5 years. The main target groups were: pregnant women (1), pregnant women who smoked (2), men at risk of cardiovascular disease (2), adult smokers (1), parents who smoked (1) and couples who both smoked (1). Interventions included family members but most did not go further by drawing on family, systemic or relational theories to harness the influence of family on smoking behaviour. Only three studies directly compared the effects on smoking behaviour of a family-based (i.e., interventions that involve a member of the family) versus an individual-based (i.e., interventions that use behaviour change techniques that focus on the individual) intervention. None of these studies found significant differences between groups on the smoking behaviour of the main target group.

Conclusions: We have yet to develop family-based smoking cessation interventions that harness or re-direct the influence of family members on smoking behaviour in a positive way. Thus, it is likely that individualised-approaches to smoking cessation will prevail.
\end{abstract}

Keywords: Smoking cessation, Family, Intervention studies, Systematic review

\section{Background}

Smoking is the most significant preventable cause of morbidity and early mortality in the world [1]. It is responsible for an estimated 6 million deaths annually [2]. Thus, helping people quit smoking is a global public health priority.

The family is an influential context in which smoking behaviour occurs [3]. For instance, parental and sibling smoking is a significant determinant of smoking uptake by children and young people [4] and cohabitants'

\footnotetext{
* Correspondence: gill.hubbard@stir.ac.uk

${ }^{1}$ School of Health Sciences, University of Stirling, Highland Campus, Centre

for Health Science, Old Perth Road, Inverness, UK

Full list of author information is available at the end of the article
}

smoking status is a major determinant for changes in smoking behaviour among adults [5-9].

Social support is the main theoretical concept used for understanding smoking cessation in families $[10,11]$. Family members' supportive and undermining behaviours are correlated with a smoker's likelihood of making a quit attempt and achieving abstinence [12-14]. Observational studies spanning several decades link the continuance of smoking to both the absence of positive partner support behaviours (e.g., expressing confidence in the smoker's ability to quit) and the presence of negative partner behaviours (e.g., commenting that 'smoking is a dirty habit') [14, 15]. Reviews of literature suggest that interventions for smoking designed to increase social support to help adults quit smoking have been 
unsuccessful [11, 16-18]. A recent systematic review by Park and colleagues of 13 interventions designed to increase support from a spouse, partner, friend, or coworker did not find greater rates of successful smoking cessation [18]. The reviewers, however, suggest that no conclusions can be made about the impact of social support on smoking cessation due to methodological limitations of the included studies as well as the likelihood that interventions did not increase the quality or quantity of partner social support [18].

The review reported in this article, addresses one of the key problems of the review by Park and colleagues, which is an assumption that social support from family is equivalent to that from friends and co-workers. A difficulty with smoking cessation interventions that harness social support to change smoking behaviour is the conflation of different sources and types of social support. These interventions invite support from spouse, intimate other, friend, relative or co-worker. The problem with this is that these relationships are different and therefore their influence on smoking behaviour also differs. A recent study about the influence of pro-smoking media (e.g., smoking in movies, advertising in magazines) on smoking in young people highlights that when participants were with friends, pro-smoking media exposures were associated with stronger smoking intentions and lower smoking refusal self-efficacy whereas these associations were not present when participants were with family [19]. A study of home smoking bans found that adolescent smoking up-take was stronger when neither parent smoked but their friends smoking behaviour did not moderate the effect of home smoking bans on adolescent smoking behaviour [20]. Consequently, the influence of family and friends on smoking behaviour is likely to differ. Family/kin has been defined as a group comprising relationships that persist over time, are emotionally intense and involve high levels of intimacy in day-to-day life [21]. Modern family structure is diverse [22] and family can refer to single and dual-parent/caregiver families, same and different sex married, civil partnership, and co-habiting couples. While many kin relations are non-voluntary, friendships (kith), in contrast, are considered profoundly voluntary and usually informal and reciprocal, based on mutual interests and social needs [23]. Neighbourly or friendship relationships foster a sense of belonging based on proximity or warmth [24], but unlike family ties, which remain fairly consistent throughout old age, contact with neighbours and friends may be subject to variation. Because they are not formally prescribed, friendships require more initiative and consequently, may decline when events such as illness or disability makes interaction difficult [25]. Relationships tend to become specialized in their provision, some of which are provided by relatives (for example, instrumental support and nurturance) and some by friends (such as social integration) [26]. Given these differences between kith and kin, it may be likely that their respective influence on smoking behaviour may also differ. This is why it is important to clearly distinguish the two sources of influence when developing smoking cessation interventions and hence our reason for conducting a review of family-based smoking cessation interventions.

The aim of this systematic review and narrative summary is to identify, describe, and synthesise the evidence about family-based interventions for smoking cessation. In doing so, we aim to develop understandings of family as the 'active ingredient' of smoking cessation interventions. In contrast to previous reviews, the focus was on family (kin) as opposed to, for instance, social support [18]. The objectives were to describe study design and methods, report intervention effects as well as to describe theories, procedures, functions and content of family-based interventions for smoking cessation. The findings will contribute towards understanding why previous family-based interventions may have limited effect and also point to ways in which future family-based smoking cessation interventions may be improved.

\section{Methods}

\section{Search strategy}

The PRISMA statement guided the conduct of this narrative review [27]. Studies were identified by structured database searches. All reviewers agreed which databases to search and search terms. One author (RP), who is a librarian and information specialist, searched 26 electronic databases (Cochrane Library, Campbell Library, EBSCO HOST (CINAHL, PsycINFO, Psychology and behavioural sciences collection, EconLit), Ovid Medline, Ovid HMIC, Ovid Embase, ProQuest (Applied Social Sciences Index and Abstracts, Social Services Abstracts, Sociological Abstracts, Australian Education Index, British Education Index, Education Resources Information Center), Prospero, PubMed, SCOPUS, Web of Science (Science Citations Index, Social Sciences Citation Index, Arts and Humanities Citation Index, Conference Proceedings Citation Index-Science, Conference Proceedings Citation Index- Social Science \& Humanities, Book Citation Index-Science, Book Citation Index - Social Science and Humanities)) in June 2014, for trials of family-based interventions targeting smoking in adults published in English language with no date restriction. As an example, search terms used for Ovid Medline are shown in Table 1, and a full search strategy is available in Additional file 1.

\section{Eligibility criteria and selection process}

All reviewers were involved in selecting articles for inclusion. One reviewer (GH) independently screened 
Table 1 Ovid Medline search terms

\begin{tabular}{|c|c|c|c|}
\hline \# & Searches & Results & Search type \\
\hline 1 & exp Smoking/or exp Smoking Cessation/ & 129169 & Advanced \\
\hline 2 & exp "Tobacco Use"/or "Tobacco Use Cessation"/or exp Tobacco/or exp Tobacco Products/or exp "Tobacco Use Cessation Products"/ & 148028 & Advanced \\
\hline 3 & 1 or 2 & 149967 & Advanced \\
\hline 4 & exp family/ & 234438 & Advanced \\
\hline 5 & (grandparent: or grand-parent: or grandfather: or grand-father: or grandmother: or grand-mother:).af. & 4543 & Advanced \\
\hline 6 & (partner: or husband: or wif: or wiv: or sibling: or brother: or sister: or mother: or father: or son: or daughter:).af. & 659383 & Advanced \\
\hline 7 & (cousin: or uncle: or aunt:).af. & 162264 & Advanced \\
\hline 8 & exp caregivers/ & 21234 & Advanced \\
\hline 9 & (caregiver: or care giver:).af. & 39284 & Advanced \\
\hline 10 & 4 or 5 or 6 or 7 or 8 or 9 & 986779 & Advanced \\
\hline 11 & 3 and 10 & 13147 & Advanced \\
\hline 12 & limit 11 to english language & 12148 & Advanced \\
\hline 13 & limit 12 to randomized controlled trial & 446 & Advanced \\
\hline 14 & (rct: or random: trial: or random: control: trial: or random: stud: or random: control: stud:).af. & 509205 & Advanced \\
\hline 15 & exp Randomized Controlled Trials as Topic/ & 93713 & Advanced \\
\hline 16 & (non random: stud: or nonrandom: stud: or non random: control: stud: or nonrandom: control: stud:).af. & 3632 & Advanced \\
\hline 17 & (non random: trial: or nonrandom: trial: or non random: control: trial: or nonrandom: control: trial:).af. & 1615 & Advanced \\
\hline 18 & (controlled before and after stud:).af. & 368 & Advanced \\
\hline 19 & (controlled before and after trial:).af. & 1176 & Advanced \\
\hline 20 & (quaziexper: or quazi-exper:).af. & 2 & Advanced \\
\hline 21 & (quasi exper: or quasiexper:).af. & 5403 & Advanced \\
\hline 22 & or/14-21 & 516489 & Advanced \\
\hline 23 & 12 and 22 & 609 & Advanced \\
\hline 24 & 13 or 23 & 609 & Advanced \\
\hline 25 & from 24 keep 1-609 & 609 & Advanced \\
\hline
\end{tabular}

titles/abstracts and all potentially relevant articles were obtained in full. Any articles that the reviewer was unsure about for inclusion were collectively discussed. Reviewers (LF, TG, GH, GO) assessed full articles against inclusion criteria set by all authors (Table 2). Inclusion criteria were based on language, type of study, participants, type of intervention and outcomes. Any disagreements were resolved through collective discussion.

\section{Data extraction processes}

Data extraction was conducted by one reviewer and then discussed and checked by at least one other reviewer. Disagreements were resolved by consensus among all of the reviewers. Data extraction forms that were used to collect data are described below.

\section{Risk of bias}

The Cochrane Risk of Bias tool was used to assess study bias [28]. This is a domain-based evaluation tool in which assessments of risk are made separately for selection, performance, detection, attrition and reporting bias, respectively. For each study, the six 'risk of bias' domains were addressed by answering a pre-specified question about the adequacy of the trial in relation to each domain, and judgment made on whether the study has high, low, or unclear risk of bias for that domain. Risk of bias was undertaken by two reviewers (TG, GO), with disagreements resolved by consensus.

\section{Methods}

The CONSORT 25-item checklist [29] was completed for each study. This checklist was used to report a study's aims and objectives, methods (e.g., design, participants, interventions, outcomes, sample size), randomization and statistical methods, participants and numbers analysed, results of analysis and discussion (e.g., limitations, generalizability and interpretation).

\section{Intervention description}

To describe the interventions, a Template for Intervention Description and Replication (TIDieR) [30] was completed for each study. If studies provided a rationale for a family- 
Table 2 Inclusion and exclusion criteria

\begin{tabular}{|c|c|}
\hline 1. Not in English language & We excluded all papers not in English because of lack of translation facilities. \\
\hline 2. Type of study & $\begin{array}{l}\text { Randomised controlled trials (RCTs), controlled non-randomised studies and } \\
\text { controlled before and after studies. Comparison groups of the family intervention } \\
\text { could be usual care, no intervention or another smoking cessation intervention. } \\
\text { Feasibility and pilot studies were included if effects of the intervention were reported. }\end{array}$ \\
\hline 3. Type of intervention & $\begin{array}{l}\text { Interventions promoting changes in adult tobacco use or prevention. Interventions } \\
\text { involving at least one family member. Interventions that gave the option of including } \\
\text { a family member or close friend/significant other were excluded. Interventions where } \\
\text { the primary aim was to reduce exposure to secondhand smoke and place of smoking } \\
\text { were excluded. Interventions delivered to whole-community or whole-population } \\
\text { level interventions such as media campaigns or changes in the local environment, } \\
\text { which included a discrete family-based intervention, were included. }\end{array}$ \\
\hline 4. Type of participants & $\begin{array}{l}\text { The target of the intervention was an adult of any gender who smoked (18 years and } \\
\text { over). One or more of the adult smoker's family had to be involved in the intervention. } \\
\text { Pregnant and non-pregnant and married and unmarried smokers were included. } \\
\text { Interventions that targeted adults and children who smoked were included but only } \\
\text { if outcomes of adults were reported separately and only if the intervention specifically } \\
\text { targeted adult smoking behaviour. Interventions that only targeted children's smoking } \\
\text { behaviour were excluded. }\end{array}$ \\
\hline 5. Type of outcomes & $\begin{array}{l}\text { Outcomes were the change in number of cigarettes smoked/smoking cessation of } \\
\text { adults. Behaviours could be measured objectively (e.g., saliva) or by self-report } \\
\text { questionnaire. If it was a multi-component intervention (e.g., family-based programme } \\
\text { administered as part of a school-based programme to prevent smoking up-take in } \\
\text { young people) then the effects of the family-based programme of the intervention } \\
\text { must have been reported separately. Studies that aimed to shift location of smoking } \\
\text { behaviour and reduce Environmental Tobacco Smoke as opposed to smoking cessation } \\
\text { were excluded. }\end{array}$ \\
\hline
\end{tabular}

based approach to help smokers to quit this was reported under the section 'Why'; the materials and procedures used with family members were reported under the section 'What'; the professional delivering the intervention to family members was reported under the section 'Who provided' and any training provided for the deliverer was also recorded; where, when and how long the intervention was delivered were reported under the sections 'Where' and 'How much', respectively; any 'tailoring' or 'modifications' to the intervention were reported under these sections; family member adherence was reported under the section 'How well.' We did not describe the individualised intervention components (e.g., materials and procedures etc.) used with the participant that was making the smoking quit attempt but only those aspects of the intervention that involved a family member. This is because the focus of this review is on family (e.g., training family members to assist their partner to make a quit attempt) as opposed to individualised (e.g., goal-setting such as setting a quit date) 'active ingredients' of smoking cessation interventions that involve family members. In addition, if the intervention included other behaviours (e.g., diet), these were also not described.

\section{Intervention function}

We used a function checklist to categorise intervention functions [31]. Only the intervention functions for family members are reported for the reason described above. The function checklist designates nine functions. Five functions can be conceptualised as individual level functions and are: education (increasing knowledge or understanding), persuasion (using communication to induce positive or negative feelings or stimulate action), incentivisation (creating expectation of reward), training (imparting skills), and enablement (increasing means/reducing barriers to increase capability or opportunity) [31]. The other four intervention functions are: coercion (creating expectation of punishment or cost), restriction (using rules to reduce the opportunity to engage in the target behaviour), environmental restructuring (changing the physical or social context), and modeling (providing an example for people to aspire to or imitate), which place more emphasis on external influences and less on personal agency [31]. More than one function could be selected, for example, if the intervention involved informing the family member about the harms of smoking, this was recorded under the function 'education' and 'persuasion.'

\section{Theory coding scheme}

The Theory Coding Scheme [32] was used to describe the theoretical basis of interventions. The Theory Coding Scheme comprises 19 items and a clear description of how to code each item. All items are listed under the following six categories, which can be used to assess the use of theory: 1) Is theory/model mentioned? 2) Are the relevant theoretical constructs targeted? 3) Is theory used to select recipients or tailored 
interventions? 4) Are the relevant theoretical constructs measured? 5) Is theory tested? 6) Is theory refined? Again, only theories relating to the family components of the interventions were recorded. Using this coding scheme provided a method for the systematic appraisal of family-based theoretical components of interventions as well as more general behaviour change theories and models.

\section{Narrative synthesis of results}

The data extraction forms described above were also used to assess if it was viable to conduct a quantitative synthesis. Using Cochrane Review guidance [28], a meta-analysis was ruled out because although most studies shared a common primary outcome (smoking cessation measured by self-report and objectively), as we describe in detail below, comparison groups (interventions versus controls), participants and key components of the interventions were not the same across studies.

Synthesis involves the collation, combination and summary of the findings of individual studies included in the systematic review [33]. Narrative synthesis comprises identifying patterns, similarities and differences about the interventions and methods reported in the included studies. Four reviewers conducted the narrative synthesis (GH, LF, GO, TG) and was carried in four stages. First, articles were divided among the reviewers who extracted data from articles about each individual trial using the data extraction forms described above. All collected data were visually presented in tabular format. Second, the data extraction forms were used to produce a narrative descriptive summary of all trials methods and bias (TG/ $\mathrm{GO})$, rationale $(\mathrm{GH})$, theories $(\mathrm{LF})$, procedures $(\mathrm{GH})$, functions $(\mathrm{GH})$, and content $(\mathrm{GH})$. These are reported in the results section below. Third, the reviewers collectively identified and discussed patterns between intervention characteristics (e.g., rationale, theories, procedures, functions and content) and the effect of the intervention on smoking cessation. The extent to which these characteristics might explain variation in the size/direction of effect was discussed. Fourth, an overall assessment of the strengths and limitations of the evidence-base about family-based approaches to help adults quit smoking were discussed by all reviewers and summarised. The outcomes of these synthesis procedures are presented in the discussion section.

\section{Results}

Figure 1 shows the flow of studies through the review process and reasons for exclusion. Searches identified 4966 potentially relevant articles, which was reduced to 2143 articles after removing duplicates. Following review of titles and abstracts, 76 full text articles were retrieved. An additional 11 articles were identified through reference lists of included articles. Of the 87 articles, eight met the selection criteria. Four studies were conducted in North America and four in European countries.

\section{Risk of bias}

The results of the 'risk of bias assessment' are presented in Table 3. We judged all trials to be at unclear or high risk of bias in the majority of domains. Random sequence generation, analytic blinding and selective reporting were all identified as high risk or unclear in the majority of studies.

\section{Primary outcome and target group}

The primary target group for smoking behaviour change varied across studies (Table 4); three targeted pregnant women (two of these targeted pregnant women who smoked) [34-36], two targeted men at risk of cardiovascular disease [37, 38], one study targeted adult smokers [39], and one targeted parents who smoked [40]. Only one study targeted couples who both smoked [41].

The smoking-related outcome in all studies was selfreported smoking abstinence (see Table 4). Self-reports were validated by objective measures (e.g., saliva thiocynate or breath carbon monoxide) in at least a sub-sample in five studies [34, 35, 37, 39, 40]. Follow-up varied from 6 weeks to 5 years; this represents a weakness of the shorter durations being unable to report comparable duration of cessation for comparison. Seven studies included spouse or partners [35-39, 41].

\section{Intervention description}

Table 5 describes key intervention components, with a particular focus on family-based components. Six were smoking behaviour only interventions [34-36, 39-41] and two were multi-component lifestyle interventions $[37,38]$. Four studies involved relatives in group-based sessions [35, 38-40]; four delivered family- or couplebased counselling, training and/or advice [34, 36, 37, 41]; one study provided written materials only to relatives (e.g., booklet, manual, guide, sheet) [35]. Health professionals (midwife, nurse, health advisor, primary care professionals) or behaviour change counsellors, delivered the interventions. Two studies mentioned that training was provided to the intervention deliverers [36, 40]. Intervention duration ranged from 5 weeks to 9 months. Two studies specified where the intervention was delivered, and both were in healthcare settings [36, 37]. No studies reported tailoring or modifying the intervention. Only one study measured the extent to which relatives were involved in the intervention [40].

\section{Intervention function}

Table 5 describes the intervention function for the family component of the intervention. Interventions could be categorised as having more than one function. An 
Table 3 Risk of bias

\begin{tabular}{|c|c|c|c|c|c|c|c|c|}
\hline \multirow[b]{2}{*}{ Authors } & \multirow[t]{2}{*}{ Design and description of comparison groups } & \multicolumn{2}{|c|}{ Selection bias } & \multirow{2}{*}{$\begin{array}{l}\text { Performance bias } \\
\text { Blinding } \\
\text { participants/ } \\
\text { personnel }\end{array}$} & \multirow{2}{*}{$\begin{array}{l}\text { Detection bias } \\
\text { Blinding } \\
\text { outcome } \\
\text { assessment }\end{array}$} & \multirow{2}{*}{$\begin{array}{l}\text { Attrition bias } \\
\text { Incomplete } \\
\text { outcome data }\end{array}$} & \multirow{2}{*}{$\begin{array}{l}\text { Reporting bias } \\
\text { Selective } \\
\text { reporting }\end{array}$} & \multirow{2}{*}{ Other bias } \\
\hline & & $\begin{array}{l}\text { Random } \\
\text { sequence } \\
\text { generation }\end{array}$ & $\begin{array}{l}\text { Allocation } \\
\text { concealment }\end{array}$ & & & & & \\
\hline $\begin{array}{l}\text { Hjermann } \\
\text { et al. [38] }\end{array}$ & $\begin{array}{l}\text { RCT - lifestyle intervention; anti-smoking advice given individually to all } \\
\text { smokers vs. usual care }\end{array}$ & Unclear & Low risk & High risk & Unclear & Low risk & Unclear & Unclear \\
\hline $\begin{array}{l}\text { McBride } \\
\text { et al. [34] }\end{array}$ & $\begin{array}{l}\text { 3-group randomised controlled intervention; pregnant women; - Usual } \\
\text { care (advice to quit and self-help guide), woman only group (usual care plus } \\
\text { late-pregnancy relapse prevention kit and } 6 \text { counselling calls), Partner-assisted } \\
\text { group (woman only group intervention plus their partners received telephone } \\
\text { counselling and a support guide) }\end{array}$ & Unclear & Unclear & High risk & Unclear & Low risk & Unclear & Unclear \\
\hline $\begin{array}{l}\text { Mclntyre- } \\
\text { Kingsolver et } \\
\text { al. [39] }\end{array}$ & $\begin{array}{l}\mathrm{RCT} \text { - a multi-component cognitive-behavioral smoking program vs. the same } \\
\text { program with spouses attending and receiving training designed to increase } \\
\text { spouse social support }\end{array}$ & High risk & Unclear & High risk & Unclear & High risk & Unclear & High risk \\
\hline $\begin{array}{l}\text { Nyborg and } \\
\text { Nevid [41] }\end{array}$ & $\begin{array}{l}\text { 3-group, randomly assigned; effort only control (written materials), therapist } \\
\text { administered treatment (couples received weekly counselling sessions), } \\
\text { self-administered/minimal contact control (behavioural treatment manual } \\
\text { and weekly telephone contact) }\end{array}$ & Unclear & Unclear & High risk & Unclear & Unclear & Unclear & Unclear \\
\hline $\begin{array}{l}\text { Øien et al. } \\
{[36]}\end{array}$ & $\begin{array}{l}\text { Controlled, prospective, intervention study of two cohorts - a prenatal, } \\
\text { structured, multi-disciplinary smoking cessation programme vs. common, } \\
\text { nationwide recommended, advice on lifestyle, including smoking behaviour }\end{array}$ & $\begin{array}{l}\text { N/A - not } \\
\text { RCT }\end{array}$ & N/A & High risk & Unclear & Unclear & Unclear & High risk \\
\hline $\begin{array}{l}\text { Patten et al. } \\
\text { [40] }\end{array}$ & Pilot, feasibility RCT - a web-based support skills training vs. health education & Unclear & Unclear & High risk & Unclear & Low risk & Low risk & Unclear \\
\hline $\begin{array}{l}\text { de Vries et al. } \\
{[35]}\end{array}$ & $\begin{array}{l}\text { Cluster RCT - Midwives in the experimental group provided brief health } \\
\text { counseling, self-help materials on smoking cessation during pregnancy } \\
\text { and early postpartum, and a partner booklet. Controls received routine care }\end{array}$ & Low risk & Unclear & High risk & Unclear & Low risk & Unclear & High risk \\
\hline $\begin{array}{l}\text { Wood et al. } \\
{[37]}\end{array}$ & $\begin{array}{l}\text { Cluster RCT - a nurse-coordinated multidisciplinary, family-based preventive } \\
\text { cardiology programme vs. usual care }\end{array}$ & Unclear & Unclear & High risk & Unclear & High risk & Low risk & Low risk \\
\hline
\end{tabular}




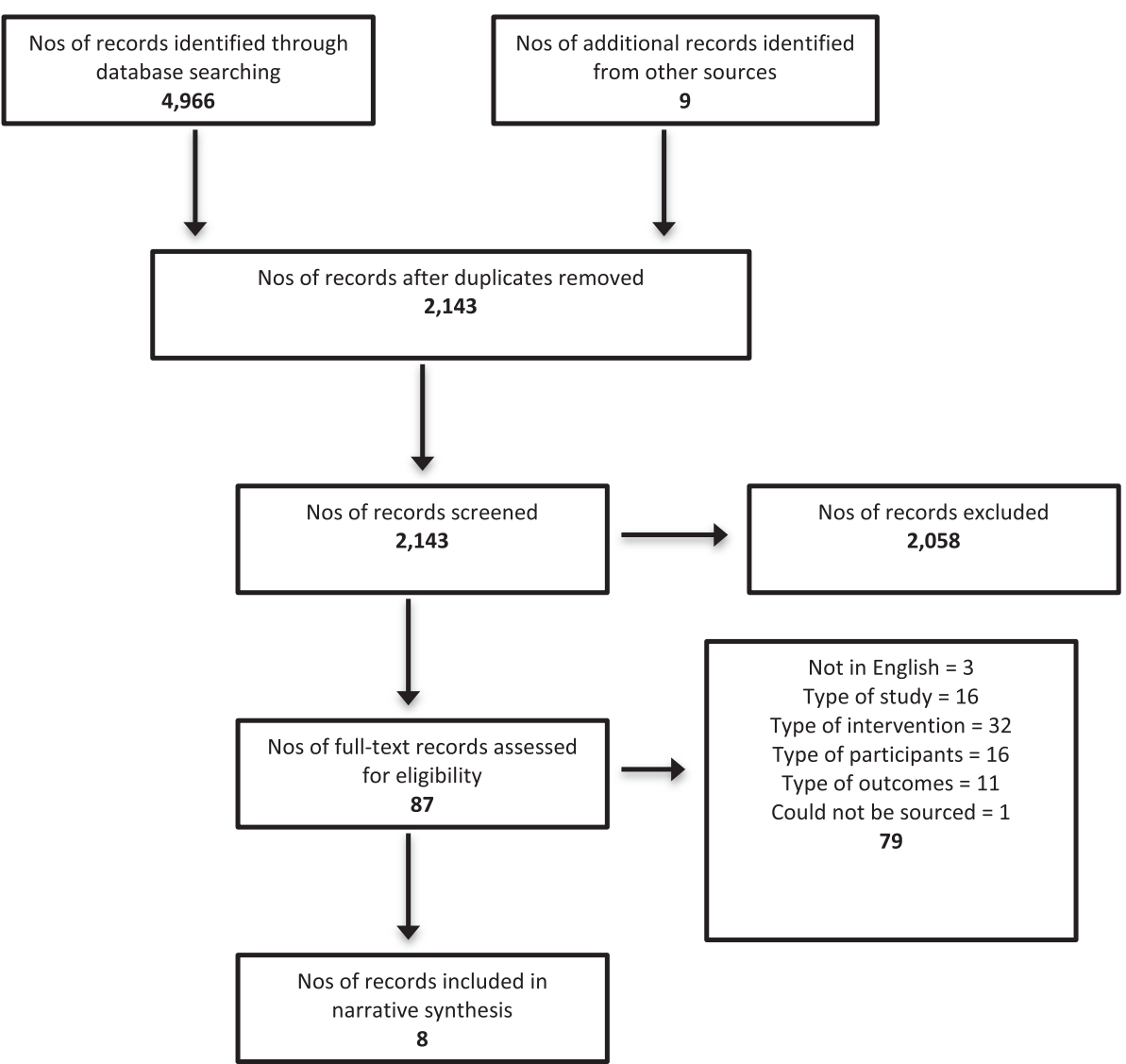

Fig. 1 Flowchart

intervention function in all but one study was categorised as 'education.' The only study that was not categorised as 'education' was categorised as 'enablement' because couples made a quit attempt together [36]. An intervention function in four studies was categorised as 'training' (i.e., giving guidance and instruction to family members on how to be supportive to their relative who is making a quit attempt) [34, 39-41]. An intervention function in one study was categorised as 'persuasion' because the intervention emphasised the harmful effects of smoking to the child to motivate them to support their parent to quit smoking [40].

\section{Theoretical models}

Table 6 summarises the underpinning theoretical approaches adopted in each of the studies. Where theories were described, this was often not in depth, and referred to social support or social influence theories. Only one study [34] explicitly referenced family theories such as marital theories, systemic theories or relational theories, and most papers did not reflect on or adapt their theoretical model in the light of the findings. Thus, studies in this review at best under-reported and at worse, under- theorised the models on which involvement of family was predicated.

\section{Effect on smoking behaviour}

Table 4 shows the results of the studies. Most studies did not assess the influence of family involvement in the intervention on smoking behaviour because there was no direct comparison of a family-based smoking cessation intervention with an individualised- based smoking cessation intervention [35-38, 40]. Hence, in most studies it is not possible to determine if family was the active ingredient' or if other behaviour change active ingredients influenced intervention effectiveness. Three studies $[34,39,41]$ however, do contribute towards developing an understanding of the influence of family involvement in smoking cessation interventions on smoking behaviour by comparing an intervention that involved family members with an intervention that did not included family members.

One study that targeted pregnant women who were current smokers or recent quitters and their intimate partners compared three groups: women in the usual care group received advice to quit and a self-help guide versus women in the women only group also receiving a 
Table 4 Methods and results of included studies

\begin{tabular}{|c|c|c|c|c|c|c|c|c|c|}
\hline Author & Country & $\begin{array}{l}\text { Main target group } \\
\text { for smoking } \\
\text { cessation }\end{array}$ & $\begin{array}{l}\text { Family member } \\
\text { involved in } \\
\text { intervention }\end{array}$ & $\begin{array}{l}\text { Smoking behaviour of } \\
\text { main target group } \\
\text { and family member }\end{array}$ & Sample* & $\begin{array}{l}\text { Reason for } \\
\text { involving family }\end{array}$ & $\begin{array}{l}\text { Smoking outcome } \\
\text { measure/length } \\
\text { follow up }\end{array}$ & $\begin{array}{l}\text { Comparison groups } \\
\text { (interventions } \\
\text { described fully } \\
\text { in Table 5) }\end{array}$ & $\begin{array}{l}\text { Results: Are family- } \\
\text { based interventions } \\
\text { more effective? }\end{array}$ \\
\hline $\begin{array}{l}\text { Hjermann } \\
\text { et al. [38] }\end{array}$ & Norway & $\begin{array}{l}\text { Men at risk of } \\
\text { coronary heart } \\
\text { disease and aged } \\
20-49 \text { years with } \\
\text { no evidence of } \\
\text { diseases of the } \\
\text { cardiovascular } \\
\text { system, diabetes } \\
\text { psychopathological } \\
\text { disease or } \\
\text { alcoholism }\end{array}$ & Wives & $\begin{array}{l}\text { Smoking behaviour } \\
\text { of the main target } \\
\text { group (men at risk } \\
\text { of coronary heart } \\
\text { disease) and family } \\
\text { members was not } \\
\text { an eligibility criteria }\end{array}$ & $\begin{array}{l}1232 \text { healthy, } \\
\text { normotensive men } \\
\text { at high risk of } \\
\text { coronary heart } \\
\text { disease; } 604 \\
\text { intervention and } \\
628 \text { control group } \\
\text { respectively. } \\
\text { Number of family } \\
\text { members not given }\end{array}$ & None given & $\begin{array}{l}\text { Self-reported } \\
\text { smoking habits; } \\
5 \text { years }\end{array}$ & $\begin{array}{l}\text { Lifestyle intervention } \\
\text { involving wives vs. } \\
\text { control group } \\
\text { (not described) }\end{array}$ & $\begin{array}{l}\text { It is unclear if the } \\
\text { 'active ingredient' } \\
\text { of the wives' } \\
\text { involvement } \\
\text { influenced } \\
\text { effectiveness } \\
\text { because } \\
\text { this was not tested } \\
\text { The intervention was } \\
\text { effective for men. } \\
\text { Tobacco consumption } \\
\text { (expressed as number } \\
\text { of cigarettes per man } \\
\text { per day; pipe smoking } \\
\text { is included taking one } \\
\text { pack of pipe tobacco } \\
\text { weekly to equal } 7 \\
\text { cigarettes daily) fell } \\
\text { about } 45 \% \text { more in } \\
\text { the intervention group } \\
\text { than in the controls }\end{array}$ \\
\hline $\begin{array}{l}\text { McBride et } \\
\text { al. [34] }\end{array}$ & $\begin{array}{l}\text { North } \\
\text { America }\end{array}$ & $\begin{array}{l}\text { Pregnant women } \\
\text { (current or recent } \\
\text { quitters) living } \\
\text { intimately with } \\
\text { their partners }\end{array}$ & Partners & $\begin{array}{l}\text { The main target } \\
\text { group was a current } \\
\text { smoker or recent } \\
\text { quitter; smoking } \\
\text { behaviour of partner } \\
\text { was not included in } \\
\text { eligibility criteria }\end{array}$ & $\begin{array}{l}583 \text { pregnant } \\
\text { women and } 583 \\
\text { partners. } 198 \\
\text { pregnant women } \\
\text { in usual care group, } \\
192 \text { pregnant } \\
\text { women in women } \\
\text { only group and } 193 \\
\text { pregnant women } \\
\text { in the partner } \\
\text { assisted group }\end{array}$ & $\begin{array}{l}\text { Marital theory } \\
\text { and empirical } \\
\text { research show } \\
\text { how marital } \\
\text { relationships } \\
\text { might affect } \\
\text { provision of } \\
\text { support for } \\
\text { smoking } \\
\text { cessation }\end{array}$ & $\begin{array}{l}\text { Self-reported } \\
\text { smoking status } \\
\text { baseline (about } \\
11 \text { weeks of } \\
\text { pregnancy), at } 28 \\
\text { weeks of pregnancy, } \\
\text { and at 2-, 6-, and } \\
12 \text {-months } \\
\text { postpartum. Saliva } \\
\text { samples were } \\
\text { collected by mail at } \\
28 \text { weeks of } \\
\text { pregnancy and at } \\
12 \text { months } \\
\text { postpartum from } \\
\text { women and } \\
\text { partners who } \\
\text { reported not } \\
\text { smoking }\end{array}$ & $\begin{array}{l}3 \text { groups: Women } \\
\text { in the usual care } \\
\text { group received } \\
\text { advice to quit and } \\
\text { a self-help guide } \\
\text { vs. women in the } \\
\text { women only group } \\
\text { also receiving a late- } \\
\text { pregnancy relapse } \\
\text { prevention kit } \\
\text { (booklet and gift } \\
\text { items) and six coun } \\
\text { seling calls vs. } \\
\text { women in the } \\
\text { partner-assisted } \\
\text { group also having } \\
\text { their partners } \\
\text { receiving telephone } \\
\text { counseling and a } \\
\text { support guide } \\
\text { emphasizing skills } \\
\text { to help the woman } \\
\text { build and maintain } \\
\text { her confidence to } \\
\text { quit smoking }\end{array}$ & $\begin{array}{l}\text { No for pregnant } \\
\text { women. Intent-to- } \\
\text { treat analyses showed } \\
\text { no significant } \\
\text { differences by } \\
\text { group in women's } \\
\text { reports of abstinence } \\
\text { at any follow-up } \\
\text { Yes for partners. In } \\
\text { late pregnancy, more } \\
\text { partners were } \\
\text { abstinent in the } \\
\text { partner assisted group } \\
(15 \%) \text { than in the } \\
\text { usual care group } \\
(5 \%), p=0.02\end{array}$ \\
\hline
\end{tabular}


Table 4 Methods and results of included studies (Continued)

\begin{tabular}{|c|c|c|c|c|c|c|c|c|c|}
\hline $\begin{array}{l}\text { McIntyre- } \\
\text { Kingsolver } \\
\text { et al. [39] }\end{array}$ & $\begin{array}{l}\text { North } \\
\text { America }\end{array}$ & $\begin{array}{l}\text { Adult smoker in a } \\
\text { committed live-in } \\
\text { relationship with a } \\
\text { spouse or spouse- } \\
\text { equivalent }\end{array}$ & $\begin{array}{l}\text { Spouse or } \\
\text { partners }\end{array}$ & $\begin{array}{l}\text { The main target } \\
\text { group was a smoker; } \\
\text { smoking behaviour } \\
\text { of partner was not } \\
\text { included in eligibility } \\
\text { criteria }\end{array}$ & $\begin{array}{l}64 \text { couples. } \\
\text { Subjects were } \\
\text { required to be } \\
\text { in a committed, } \\
\text { live-in relationship } \\
\text { with a spouse or } \\
\text { spouse-equivalent } \\
\text { who was willing } \\
\text { to attend the } \\
\text { treatment sessions }\end{array}$ & $\begin{array}{l}\text { Perceived } \\
\text { helpfulness from } \\
\text { a spouse and } \\
\text { verbal } \\
\text { encouragement } \\
\text { and cooperative } \\
\text { participation } \\
\text { may be an asset } \\
\text { to cessation and } \\
\text { maintenance }\end{array}$ & $\begin{array}{l}\text { Self-report } \\
\text { smoking status } \\
\text { and abstinence } \\
\text { and reports of } \\
\text { significant others; } \\
\text { saliva thiocyanate } \\
\text { (SCN) and/or level } \\
\text { of alveolar carbon } \\
\text { monoxide (CO); } \\
1 \text { and } 6 \text { months } \\
\text { follow up }\end{array}$ & $\begin{array}{l}\text { Spouse training vs. } \\
\text { usual treatment to } \\
\text { aid a smoking } \\
\text { cessation }\end{array}$ & $\begin{array}{l}\text { No. There was a } \\
\text { consistent trend in } \\
\text { favour of the partner } \\
\text { training treatment, but } \\
\text { even the largest } \\
\text { difference ( } 72.7 \% \text { vs. } \\
48.4 \% \text { abstinent), at } \\
\text { the end of treatment, } \\
\text { was not significant. }\end{array}$ \\
\hline $\begin{array}{l}\text { Nyborg } \\
\text { and Nevid } \\
{[41]}\end{array}$ & $\begin{array}{l}\text { North } \\
\text { America }\end{array}$ & $\begin{array}{l}\text { Couples who } \\
\text { both smoke and } \\
\text { live together and } \\
\text { both seeking to } \\
\text { quit or reduce } \\
\text { smoking and } \\
\text { both smoking } \\
>20 \text { cigarettes } \\
\text { a day }\end{array}$ & $\begin{array}{l}\text { Spouse or } \\
\text { partner who } \\
\text { also smoked }\end{array}$ & $\begin{array}{l}\text { To be eligible both } \\
\text { individuals that } \\
\text { comprised the } \\
\text { couple had to smoke }\end{array}$ & $\begin{array}{l}40 \text { couples living } \\
\text { together randomly } \\
\text { assigned to } 1 \text { of } 5 \\
\text { treatment groups }\end{array}$ & Social support & $\begin{array}{l}\text { Self-reported } \\
\text { abstinence post- } \\
\text { treatment and } \\
3 \text { and } 6 \text { months }\end{array}$ & $\begin{array}{l}5 \text { different types of } \\
\text { smoking cessation } \\
\text { interventions } \\
\text { compared: } 2 \text { couple- } \\
\text { based and } 2 \\
\text { individual-based } \\
\text { therapy groups and } \\
\text { a group just given } \\
\text { written materials }\end{array}$ & $\begin{array}{l}\text { No. Abstinence rates } \\
\text { for couples were not } \\
\text { significantly different } \\
\text { across groups at } \\
\text { follow-up intervals, }\end{array}$ \\
\hline $\begin{array}{l}\text { Øien et al. } \\
\text { [36] }\end{array}$ & Norway & Pregnant women & $\begin{array}{l}\text { Spouse or } \\
\text { partners }\end{array}$ & $\begin{array}{l}\text { The smoking } \\
\text { behaviour of the } \\
\text { main target group } \\
\text { (pregnant women) } \\
\text { and the family } \\
\text { member (partner) } \\
\text { was not included } \\
\text { in the eligibility } \\
\text { criteria }\end{array}$ & $\begin{array}{l}\text { Pregnant women } \\
\text { and partners: } \\
\text { intervention cohort } \\
(N=2051) \text { and the } \\
\text { control cohort } \\
(N=1788) \text {. Number } \\
\text { of partners not } \\
\text { given }\end{array}$ & None given & $\begin{array}{l}\text { Self-reported } \\
\text { smoking behaviour; } \\
9-12 \text { weeks } \\
\text { gestation, and at } 6 \\
\text { weeks after delivery }\end{array}$ & $\begin{array}{l}\text { A cohort given } \\
\text { smoking cessation } \\
\text { intervention vs. a } \\
\text { cohort not given the } \\
\text { intervention }\end{array}$ & $\begin{array}{l}\text { It is unclear if the } \\
\text { 'active ingredient' of } \\
\text { partner spouses'/ } \\
\text { partners' involvement } \\
\text { influenced } \\
\text { effectiveness because } \\
\text { this was not tested } \\
\text { The intervention was } \\
\text { not effective for } \\
\text { pregnant women. Data } \\
\text { stratified according to } \\
\text { smoking behaviour at } \\
\text { the beginning of } \\
\text { pregnancy } \\
\text { demonstrated that in } \\
\text { the intervention } \\
\text { cohort only one in } \\
\text { four of the smoking } \\
\text { women continued to } \\
\text { smoke from the } \\
\text { beginning of } \\
\text { pregnancy until } \\
\text { inclusion, with no } \\
\text { significant difference } \\
\text { between the cohorts. } \\
\text { Yes for partners. In } \\
\text { contrast, most men } \\
\text { continued to smoke } \\
\text { in the same period, } \\
\text { but significantly fewer }\end{array}$ \\
\hline
\end{tabular}


Table 4 Methods and results of included studies (Continued)

\begin{tabular}{|c|c|c|c|c|c|}
\hline $\begin{array}{l}\text { Patten et } \\
\text { al. [40] }\end{array}$ & $\begin{array}{l}\text { North } \\
\text { America }\end{array}$ & $\begin{array}{l}\text { Parent (biological, } \\
\text { adopted, step } \\
\text { parent or adult } \\
\text { guardian) who } \\
\text { currently smoked } \\
\geq 5 \text { cigarettes } \\
\text { per day }\end{array}$ & $\begin{array}{l}\text { Child aged 13- } \\
19 \text { years, never } \\
\text { smoked or if a } \\
\text { former smoker } \\
\text { had not smoked } \\
\text { during past } 6 \\
\text { months, and } \\
\text { interested in } \\
\text { helping parent } \\
\text { quit }\end{array}$ & $\begin{array}{l}\text { The main target } \\
\text { group (parent) was } \\
\text { a current smoker and } \\
\text { the family member } \\
\text { (child) either never } \\
\text { smoked or had quit }\end{array}$ & $\begin{array}{l}40 \text { non-smoking } \\
\text { adolescents } \\
\text { (13-19 years) } \\
\text { interested in } \\
\text { helping a parent } \\
\text { (biological, } \\
\text { adopted, step } \\
\text { parent or adult } \\
\text { guardian) to quit } \\
\text { who currently a) } \\
\text { smoked }>=5 \text { ciga } \\
\text { rettes per day }\end{array}$ \\
\hline
\end{tabular}
de Vries
al. [35] Pregnant women pregnant more than twice Partners who smoked were involved, otherwise

thecause assumed partners not that these women involved

would be very unlikely to change their smoking

behaviour) and

smoked at least

1 cigarette a day

\section{The main target \\ 141 and 177} group (pregnant women) was a their partner also smoked then they were included in the intervention current smoker. If pregnant wome in intervention and control groups completed first questionnaires,

respectively.

Number of partners not given
Adolescents are At each follow-up concerned about par point prevalence oke and defined as no wish to help cigarettes smoked (not even a puff) (not even a puff)
for previous 7 days. Confirmed at 6 months by salivary cotinine

concentration of $<15$ $\mathrm{ng} / \mathrm{ml}$. Quit attempts since time of enrolment assessed at each followup; 6 and 12 weeks and 6 months

Self-reported: 7-day abstinence, Continuous abstinence, Continuous abstinence (6 weeks postpartum), Partner smoking; Measures at pre-test and 6 weeks post-intervention and 6 weeks postpartum Urine-cotinine levels measured by gas chromatography/mass spectrometry in sub-sample

in the intervention cohort

2 smoking cessation It is unclear if the interventions 'active ingredient' of compared: Health child involvement education vs. support influenced

training

effectiveness because this was not tested. The study included two different familybased interventions and about half of

parents in each group reported a quit attempt since study enrolment

Brief health

counseling, selfhelp materials on smoking cessation during pregnancy and early

postpartum, and a partner booklet vs. usual care and a general folder from the Dutch Smoking and Health Foundation
It is unclear if the

'active ingredient' of partner spouses'/

partners' involvement influenced

effectiveness because this was not tested

The intervention was effective for pregnant women. Significant differences were found between the two groups. Nineteen percent of the experimental group reported 7-day abstinence compared to $7 \%$ of the control group at first follow up, and 21 and $12 \%$, respectively, at second follow up. For continuous abstinence these percentages

were $12 \%$ in the experimental group and $3 \%$ in the control group

The intervention was not effective for partners. No significant differences between 
Table 4 Methods and results of included studies (Continued)

\begin{tabular}{|c|c|c|c|c|c|c|c|c|c|}
\hline & & & & & & & & & $\begin{array}{l}\text { the two groups were } \\
\text { found for partners }\end{array}$ \\
\hline $\begin{array}{l}\text { Wood et } \\
\text { al. [37] }\end{array}$ & $\begin{array}{l}\text { European } \\
\text { countries: } \\
\text { France, Italy, } \\
\text { Poland, } \\
\text { Spain, } \\
\text { Sweden, UK, } \\
\text { Denmark, } \\
\text { Italy,Poland, } \\
\text { Spain, the } \\
\text { Netherlands }\end{array}$ & $\begin{array}{l}\text { Patients at least } \\
50 \text { years of age } \\
\text { and less than } \\
80 \text { years old, with } \\
\text { no history of } \\
\text { cardiovascular } \\
\text { disease but at risk } \\
\text { of coronary heart } \\
\text { disease with no } \\
\text { history of severe } \\
\text { heart failure, severe } \\
\text { physical disability, } \\
\text { or dementia and } \\
\text { their partners }\end{array}$ & $\begin{array}{l}\text { Spouse or } \\
\text { partners }\end{array}$ & $\begin{array}{l}\text { Smoking behaviour } \\
\text { of the main target } \\
\text { group (men at risk } \\
\text { of coronary heart } \\
\text { disease) and family } \\
\text { members was not } \\
\text { an eligibility criteria }\end{array}$ & $\begin{array}{l}1589 \text { and } 1499 \\
\text { patients with } \\
\text { coronary heart } \\
\text { disease in hospitals } \\
\text { and } 1189 \text { and } 1128 \\
\text { at high risk were } \\
\text { assigned to } \\
\text { intervention and } \\
\text { usual care groups. } \\
860 \text { patients and } \\
410 \text { partners } \\
\text { participated in } \\
\text { hospital intervention } \\
\text { programme; } 947 \\
\text { high-risk patients } \\
\text { and 204 partners } \\
\text { participated in } \\
\text { general practice } \\
\text { intervention } \\
\text { programme }\end{array}$ & Provide support & $\begin{array}{l}\text { Self-reported cessation } \\
\text { of smoking, validated } \\
\text { by a breath carbon } \\
\text { monoxide concentration } \\
\text { of less than } 6 \text { parts per } \\
\text { million; } 12 \text { months } \\
\text { follow up }\end{array}$ & $\begin{array}{l}2 \text { lifestyle intervention } \\
\text { groups (hospital and } \\
\text { general practice } \\
\text { groups) vs. usual care } \\
\text { (not described) }\end{array}$ & $\begin{array}{l}\text { It is unclear if the } \\
\text { 'active ingredient' of } \\
\text { partner spouses'/ } \\
\text { partners' involvement } \\
\text { influenced } \\
\text { effectiveness because } \\
\text { this was not tested } \\
\text { The intervention was } \\
\text { effective for patients } \\
\text { Among patients with } \\
\text { coronary heart disease } \\
\text { who reported smoking } \\
\text { in the month before } \\
\text { their cardiac event, a } \\
\text { higher proportion in } \\
\text { the intervention group } \\
\text { were not smokers at } \\
1 \text { year compared with } \\
\text { the usual-care group } \\
\text { (for example, hospital } \\
\text { intervention vs. usual } \\
\text { care was } 58 \% \text { vs. } \\
47 \% \text { p=0.06) } \\
\text { The intervention was } \\
\text { not effective for } \\
\text { partners. Non-smoking } \\
\text { at } 1 \text { year was greater, } \\
\text { although not } \\
\text { significantly so, in } \\
\text { the partners of patients } \\
\text { in the intervention } \\
\text { groups than in usual- } \\
\text { care groups }\end{array}$ \\
\hline
\end{tabular}


Table 5 Intervention description

\begin{tabular}{|c|c|c|c|c|c|c|c|}
\hline Author & Behaviours & Materials and procedures & $\begin{array}{l}\text { Intervention } \\
\text { function(s) }\end{array}$ & Deliverers & Duration & Tailoring & Family involvement \\
\hline $\begin{array}{l}\text { Hjermann } \\
\text { et al. [38] }\end{array}$ & Smoking, diet & $\begin{array}{l}\text { The wives of the subjects were invited in groups of } 30-40 \\
\text { together with their husbands for diet and smoking } \\
\text { information. }\end{array}$ & Education & Not described & Not described & No & Not measured \\
\hline $\begin{array}{l}\text { McBride et } \\
\text { al. [34] }\end{array}$ & Smoking & $\begin{array}{l}6 \text { counseling telephone calls (three in pregnancy and } \\
\text { three in postpartum) using motivational interviewing } \\
\text { techniques. An "It Takes Two" booklet and companion } \\
\text { video were developed to guide couples in discussing } \\
\text { support behaviors related to the woman's smoking. }\end{array}$ & $\begin{array}{l}\text { Education and } \\
\text { training }\end{array}$ & Health advisor & Not described & No & Not measured \\
\hline $\begin{array}{l}\text { McIntyre- } \\
\text { Kingsolver } \\
\text { et al. [39] }\end{array}$ & Smoking & $\begin{array}{l}\text { Spouse training } \\
\text { Common examples of helpful or unhelpful behaviors } \\
\text { were pointed out and the group was also asked to } \\
\text { contribute examples from their own experience. } \\
\text { Guided group discussions and direct instruction } \\
\text { were used to try and increase positive or decrease } \\
\text { negative spouse behaviors. Spouses were encouraged } \\
\text { at all stages to help problem solve difficult situations } \\
\text { (e.g., quit day) and to reward subjects for making small } \\
\text { steps in changing their habit. It was emphasized that } \\
\text { the posttreatment support and assistance that spouses } \\
\text { provided was crucial to the success of the subject. } \\
\text { Subjects were also encouraged to reward their spouses } \\
\text { for participating in the program and for helping them. }\end{array}$ & $\begin{array}{l}\text { Education and } \\
\text { training }\end{array}$ & $\begin{array}{l}\text { Counsellors were two } \\
\text { clinical psychology } \\
\text { graduate students with } \\
\text { experience of conducting } \\
\text { smoking cessation groups. }\end{array}$ & $\begin{array}{l}\text { Six weekly two-hour } \\
\text { groups sessions }\end{array}$ & No & Not measured \\
\hline $\begin{array}{l}\text { Nyborg and } \\
\text { Nevid [41] }\end{array}$ & Smoking & $\begin{array}{l}\text { Couples received additional written materials which } \\
\text { provided instructions in providing mutual support for } \\
\text { smoking reduction and cessation) The techniques } \\
\text { included mutual modeling of appropriate nonsmoking } \\
\text { behavior in smoking-related contexts (e.g., talking on } \\
\text { the telephone without smoking), mutual monitoring } \\
\text { (systematically counting each other's cigarettes), partner } \\
\text { reinforcement for habit change, and couple reinforcement } \\
\text { contingent upon achievement of mutual goals in changing } \\
\text { smoking habits (e.g., the couple selects a shared reward for } \\
\text { mutual abstinence during a predetermined period of time). } \\
\text { Couples receiving therapist-administered treatment reviewed } \\
\text { their progress in implementing these mutual support strategies } \\
\text { and received therapist feedback in their treatment sessions. } \\
\text { Weekly telephone contact was maintained with minimal } \\
\text { contact couples during which partners reported on each } \\
\text { other's progress and received therapist feedback. }\end{array}$ & $\begin{array}{l}\text { Education and } \\
\text { training }\end{array}$ & Behaviour therapists & 8 weeks & No & Not reported \\
\hline $\begin{array}{l}\text { Øien et al. } \\
\text { [36] }\end{array}$ & Smoking & $\begin{array}{l}\text { Women were invited to bring their partners to the individual } \\
\text { consultations, and if he was a smoker they were encouraged } \\
\text { to make a smoking cessation effort together }\end{array}$ & Enablement & $\begin{array}{l}\text { Primary care professionals: } \\
\text { GPs and midwives, public } \\
\text { health nurses. Offered a } \\
3 \mathrm{~h} \text { course to improve } \\
\text { smoking cessation } \\
\text { counselling skills }\end{array}$ & $\begin{array}{l}8 \text { to } 10 \text { prenatal } \\
\text { consultations in } \\
\text { primary care }\end{array}$ & No & Not measured \\
\hline $\begin{array}{l}\text { Patten et al. } \\
\text { [40] }\end{array}$ & Smoking & $\begin{array}{l}\text { Health education control group } \\
11 \text { page booklet: }\end{array}$ & & $\begin{array}{l}6 \text { research counsellors } \\
\text { with Masters or }\end{array}$ & $\begin{array}{l}5 \text { weeks } \times 1 \\
\text { session } \times 30 \text { min }\end{array}$ & No & \\
\hline
\end{tabular}


Table 5 Intervention description (Continued)

\begin{tabular}{|c|c|c|c|c|c|c|c|}
\hline & & $\begin{array}{l}\text { (1) education on the health effects of smoking, (2) nicotine } \\
\text { dependence and withdrawal symptoms, (3) readiness to quit, } \\
\text { (4) basic communication skills between the adolescent and } \\
\text { parent, (5) strategies on how to approach the parent about } \\
\text { their smoking and quitting, (6) strategies on how to elicit } \\
\text { from the parent the pros and cons of continued smoking } \\
\text { and quitting, (7) triggers for relapse. } \\
5 \text { web-based group sessions for Support Skills Training: } \\
\text { (1) rationale for treatment (i.e., Raise awareness of possible } \\
\text { personal benefits of treatment) (e.g., dealing with anger or } \\
\text { distress regarding parent's smoking behavior) - "You can't } \\
\text { control your parent, only yourself. It is important to focus } \\
\text { on what you can do as a support person", setting S.M.A.R.T. } \\
\text { goals and use of self-rewards and education on nicotine } \\
\text { dependence; (2) provide education on motivation and } \\
\text { readiness to quit; (3) using positive behaviors and statements } \\
\text { to encourage their parent to move forward in the quitting } \\
\text { process; (4) provide education on how smokers quit (i.e., } \\
\text { setting a quit date, nicotine dependence treatments, coping } \\
\text { with triggers, and social support); (5) provide education on } \\
\text { lapse, relapse and how to reinforce (shape) progress made } \\
\text { by the smoker and goal setting after the program ends. } \\
\text { Web-based message board to post questions }\end{array}$ & $\begin{array}{l}\text { Education and } \\
\text { training and } \\
\text { persuasion }\end{array}$ & $\begin{array}{l}\text { Bachelors degree in } \\
\text { behavioural health or } \\
\text { social science. Training } \\
\text { provided to deliver } \\
\text { the intervention }\end{array}$ & & & $\begin{array}{l}95 \%(19 / 20) \text { adolescents } \\
\text { completed all sessions and } \\
79 \% \text { read the booklet }\end{array}$ \\
\hline $\begin{array}{l}\text { de Vries et } \\
\text { al. [35] }\end{array}$ & Smoking & $\begin{array}{l}\text { Because pregnant women motivated to quit smoking } \\
\text { encounter difficulties to quit in the presence of a } \\
\text { smoking partner a booklet was made for partners who } \\
\text { also smoked }\end{array}$ & Education & Midwife & Not described & No & Not measured \\
\hline $\begin{array}{l}\text { Wood et al. } \\
\text { [37] }\end{array}$ & $\begin{array}{l}\text { Smoking, diet, } \\
\text { exercise }\end{array}$ & $\begin{array}{l}\text { Couples attended lifestyle assessment and group workshop } \\
\text { about lifestyle risk factors for coronary heart disease and } \\
\text { cardiovascular risks. Patients were provided with a personal } \\
\text { record card for lifestyle and risk factor targets and their } \\
\text { families with family support packs. }\end{array}$ & Education & Nurse & $\begin{array}{l}8 \text { weekly sessions in } \\
\text { hospital or general } \\
\text { practice }\end{array}$ & No & Not measured \\
\hline
\end{tabular}


Table 6 Theoretical models informing the interventions

\begin{tabular}{|c|c|c|c|c|c|c|}
\hline Study & $\begin{array}{l}\text { Is theory/model } \\
\text { mentioned? }\end{array}$ & $\begin{array}{l}\text { Are the relevant theoretical } \\
\text { constructs targeted? }\end{array}$ & $\begin{array}{l}\text { Is theory used to select recipients } \\
\text { or tailored interventions? }\end{array}$ & $\begin{array}{l}\text { Are the relevant theoretical } \\
\text { constructs measured? }\end{array}$ & $\begin{array}{l}\text { Is family-related } \\
\text { theory tested? }\end{array}$ & $\begin{array}{l}\text { Is theory } \\
\text { refined? }\end{array}$ \\
\hline Hjermann et al. [38] & Not reported & Not reported & Not reported & Not reported & Not reported & Not reported \\
\hline McBride et al. [34] & $\begin{array}{l}\text { Social support and marital } \\
\text { theory is referred to. }\end{array}$ & $\begin{array}{l}\text { Yes. Intervention objectives } \\
\text { were to (1) encourage } \\
\text { couple communication } \\
\text { about helpful and unhelpful } \\
\text { support behaviors, (2) assist } \\
\text { partners in developing } \\
\text { alternatives to negative } \\
\text { behaviors, (3) prompt } \\
\text { couples to make plans } \\
\text { for handling high-risk } \\
\text { situations, and (4) when } \\
\text { appropriate, encourage } \\
\text { and assist partner smoking } \\
\text { cessation.An "It Takes Two" } \\
\text { booklet and companion } \\
\text { video were developed } \\
\text { to guide couples in discussing } \\
\text { support behaviors related } \\
\text { to the woman's } \\
\text { smoking. }\end{array}$ & No & $\begin{array}{l}\text { Yes. Partner Interaction } \\
\text { Questionnaire to assess } \\
\text { positive and negative } \\
\text { perceived and provided } \\
\text { support for cessation. }\end{array}$ & $\begin{array}{l}\text { Intervention impact on } \\
\text { support was measured. } \\
\text { Women in all } 3 \text { groups } \\
\text { consistently reported } \\
\text { a decline in positive } \\
\text { partner support from } \\
\text { baseline to 12-month } \\
\text { Postpartum, negative } \\
\text { support decreased } \\
\text { through pregnancy, } \\
\text { but increased postpartum. } \\
\text { Partners reported little } \\
\text { change in positive and } \\
\text { negative smoking-specific } \\
\text { support that they gave in } \\
\text { the same time frame. }\end{array}$ & Not reported \\
\hline $\begin{array}{l}\text { Mclntyre-Kingsolver } \\
\text { et al. [39] }\end{array}$ & $\begin{array}{l}\text { Social support is cited as } \\
\text { the driving theory, referring } \\
\text { to a previous study which } \\
\text { found that perceived } \\
\text { helpfulness from a spouse } \\
\text { during treatment was } \\
\text { significantly related to } \\
\text { smokers achieving and } \\
\text { maintaining abstinence. }\end{array}$ & $\begin{array}{l}\text { Yes. Common examples } \\
\text { of helpful or unhelpful } \\
\text { behaviors were discussed. } \\
\text { Guided group discussions } \\
\text { and direct instruction were } \\
\text { used to try and increase } \\
\text { positive or decrease negative } \\
\text { spouse behaviors. Spouses } \\
\text { were encouraged at all stages } \\
\text { to help problem solve difficult } \\
\text { situations (e.g., quit day) and } \\
\text { to reward subjects for making } \\
\text { small steps in changing their } \\
\text { habit. It was emphasized that } \\
\text { the post-treatment support } \\
\text { and assistance that spouses } \\
\text { provided was crucial to the } \\
\text { success of the subject. Subjects } \\
\text { were also encouraged to } \\
\text { reward their spouses for } \\
\text { participating in the program } \\
\text { and for helping them. }\end{array}$ & $\begin{array}{l}\text { Relatives are guided on how } \\
\text { to be more/less supportive. }\end{array}$ & $\begin{array}{l}\text { Partner Interaction Questionnaire } \\
\text { measured the impact of the } \\
\text { spouse-training treatment } \\
\text { component. This 61-item } \\
\text { tool taps into a variety of } \\
\text { smoking-related spousal } \\
\text { interactions. }\end{array}$ & $\begin{array}{l}\text { Influence of social support } \\
\text { is measured and found to } \\
\text { not be related to self- } \\
\text { reported smoking status } \\
\text { at follow-up. }\end{array}$ & Not reported \\
\hline
\end{tabular}


Table 6 Theoretical models informing the interventions (Continued)

\begin{tabular}{|c|c|c|c|c|c|c|}
\hline $\begin{array}{l}\text { Nyborg and } \\
\text { Nevid [41] }\end{array}$ & Social support & $\begin{array}{l}\text { Yes. Couples received additional } \\
\text { written materials which provided } \\
\text { instructions in providing mutual } \\
\text { support for smoking } \\
\text { reduction and cessation) } \\
\text { The techniques included } \\
\text { mutual modeling of appropriate } \\
\text { nonsmoking behavior in } \\
\text { smoking-related contexts (e.g., } \\
\text { talking on the telephone } \\
\text { without smoking), mutual } \\
\text { monitoring (systematically } \\
\text { counting each other's } \\
\text { cigarettes), partner reinforcement } \\
\text { for habit change, and couple } \\
\text { reinforcement contingent upon } \\
\text { achievement of mutual goals } \\
\text { in changing smoking habits } \\
\text { (e.g., the couple selects a shared } \\
\text { reward for mutual abstinence } \\
\text { during a predetermined period } \\
\text { of time). Couples receiving } \\
\text { therapist-administered treatment } \\
\text { reviewed their progress in } \\
\text { implementing these mutual } \\
\text { support strategies and received } \\
\text { therapist feedback in their } \\
\text { treatment sessions. Weekly } \\
\text { telephone contact was } \\
\text { maintained with minimal } \\
\text { contact couples during which } \\
\text { partners reported on each } \\
\text { other's progress and } \\
\text { received therapist feedback. }\end{array}$ & No & Not reported & Not reported & Not reported \\
\hline Øien et al. [36] & Not reported & Not reported & Not reported & Not reported & Not reported & Not reported \\
\hline Patten et al. [40] & $\begin{array}{l}\text { No explicit theory } \\
\text { provided, but the link } \\
\text { between adolescents } \\
\text { influencing parental } \\
\text { smoking is proposed } \\
\text { as promoting health } \\
\text { and reducing second- } \\
\text { hand smoke exposure. }\end{array}$ & Not reported & Not reported & Not reported & Not reported & Not reported \\
\hline
\end{tabular}


Table 6 Theoretical models informing the interventions (Continued)

\begin{tabular}{|c|c|c|c|c|c|c|}
\hline de Vries et al. [35] & $\begin{array}{l}\text { Theory of behaviour } \\
\text { change, based on } \\
\text { communication } \\
\text { techniques, and the } \\
\text { "health communication } \\
\text { persuasion matrix", } \\
\text { based on social } \\
\text { influence theory and } \\
\text { self-efficacy. The authors } \\
\text { note that reviews on } \\
\text { smoking and pregnant } \\
\text { women suggest to } \\
\text { include partner } \\
\text { smoking in programs } \\
\text { since smoking status } \\
\text { of the partner is a } \\
\text { chief predictor of } \\
\text { postpartum relapse }\end{array}$ & $\begin{array}{l}\text { The intervention was } \\
\text { focused on pregnant } \\
\text { women. A booklet was } \\
\text { provided to smoking fathers, } \\
\text { encouraging cessation and } \\
\text { support to their partner. }\end{array}$ & $\begin{array}{l}\text { The booklet was given to } \\
\text { women with smoking } \\
\text { partners. }\end{array}$ & $\begin{array}{l}\text { No, but partner smoking } \\
\text { was measured. }\end{array}$ & Not reported & Not reported \\
\hline Wood et al. [37] & Not reported & Not reported & Not reported & Not reported & Not reported & Not reported \\
\hline
\end{tabular}


late-pregnancy relapse prevention kit (booklet and gift items) and six counseling calls versus women in the partner-assisted group also having their partners receiving telephone counseling and a support guide emphasizing skills to help the woman build and maintain her confidence to quit smoking [34]. The study found no significant differences by group in women's reports of abstinence at any follow-up but found that more partners were abstinent in the partner assisted group (15\%) than in the usual care group (5\%), $p=0.02$ [34]. Another study that targeted adult smokers compared two groups: spouse training versus usual treatment to aid a smoking cessation [39]. The results show a consistent trend in favour of the partner training treatment, but even the largest difference (72.7 \% vs. $48.4 \%$ abstinent), at the end of treatment, was not significant [39]. The only study that targeted couples who smoked compared five different types of interventions: two couple-based and two individual-based therapy groups and a group just given written materials [41]. The study found that abstinence rates for couples were not significantly different across groups at follow-up.

\section{Discussion}

Very few RCTs of smoking cessation interventions that involve family members have been conducted. Studies were too dissimilar to conduct a meaningful metaanalysis; nevertheless, our narrative synthesis of the evidence about family-based interventions for smoking cessation enables us to make a number of observations.

First, it is not possible to determine if family is a critical 'active ingredient' in smoking cessation interventions primarily because most studies did not include a direct comparison of a family-based smoking cessation intervention with an individualised- based smoking cessation intervention. This represents a major limitation of family-based smoking cessation intervention studies because it means that it is not possible to determine if family is the 'active ingredient.' Of the three studies that did directly compare the effects on smoking behaviour of a family-based (i.e., interventions that involve a member of the family) versus an individual-based (i.e., interventions that use behaviour change techniques that focus on the individual such as, setting a date for a quit attempt) intervention, the evidence suggests that family is not a key 'active ingredient'. Although we know from epidemiological studies that family members influence smoking behaviour of other family members [4-9], we have yet to develop family-based smoking cessation interventions that harness or re-direct that influence in a positive way. Thus, it is likely that individualisedapproaches to smoking cessation will prevail.

Second, we found no trials of family-based smoking interventions (defined as those targeting adult smokers and involving at least one relative) conducted outside North America and Europe. This impairs our understandings about smoking cessation interventions given that family systems vary [42] and so we might expect components of family-based smoking cessation interventions in different countries to reflect these differences.

Third, there is lack of clarity about reasons for the involvement of family members in smoking cessation interventions. Some of the interventions used social support or social influence theories to aid cessation but many did not provide a coherent rationale for adopting a family-based approach. In addition, our review highlights methodological and reporting limitations of the majority of the studies, which means that the effect of family-based smoking interventions remains uncertain. It is thus premature to draw definitive conclusions about the effect of family-based interventions to help people quit smoking.

These findings are perhaps not surprising. In the past, family-based social support interventions to help adults quit smoking have also shown disappointing results, leading those who had developed these interventions in the 1980 s and 1990s to conclude that modifying longstanding interpersonal relationships to impact smoking cessation is extremely difficult [43, 44]. However, a review of these interventions suggest that their failure may reflect methodological and theoretical limitations and in particular, over-reliance on a social support model where spouses/partners learn, practice and apply various coping, problem-solving or support skills to augment smoking cessation [15]. Rohrbaugh and colleagues [15] proposed instead the use of a systemic/interactional framework where family members are not merely 'adjunct therapists' but are perceived as full participants with a stake in the changes that will occur. A key aim of the systemic approach advocated by Rohrbaugh and colleagues [15] is to help couples negotiate relational functions that smoking serves such as, regulating emotional expression and interpersonal closeness (e.g., smoking may convey messages such as 'let's relax together'). The reviewers developed FAMCON, which is based on family-systems principles and in a study involving 20 couples in which one partner (the primary smoker) continued to smoke despite having or being at significant risk for heart or lung disease. The study found that $50 \%$ rate of stable abstinence was achieved by primary smokers over at least 6 months, which exceeds benchmark success rates reported in the literature for other comparably intensive interventions. The findings suggest that a couple-focused intervention different in concept and format from social support interventions tested in the past may hold promise for health-compromised smokers [45]. FAMCON however, is not included in this review because it did not include a control group. 
Fourth, our review highlights lack of conceptual clarity about family and how it differs to other relationships such as friendships. It remains unclear what the active ingredients of family are that make it such an important context for patterns of smoking behaviour and smoking cessation efforts. Much health research located within the social sciences tends to define family loosely, often allowing participants to self-determine who and what constitutes family. McDaniel and colleagues [46] for instance, define family as "any group of people related either biologically, emotionally or legally, i.e., the group of people that the patient defines as significant for his/her wellbeing"(p2). This conceptual flexibility reflects the constructed and culturally bound nature of social relations and influence. Some studies propose the notion of a "psychological family" where the family is defined as those members who are psychologically connected [47], including "friends-like family" (p283). These social definitions stand in contrast to biomedical conceptualisations of families as sharing genetic or environmental effects, and reflect the interest in relational influence and support, rather than biological drivers. Nevertheless, unless interventionists are clear why they are proposing a family-based approach then procedures, function, and content of intervention delivery are likely to underutilise what it is about family that makes it such a potent system for promoting behaviour change.

\section{Limitations}

For this review we comprehensively searched a number of databases, however, we did not search for non-English publications or unpublished literature. Further, researchers do not always distinguish between, or clarify whether it is a family member or friend etc. who provides support, which increases the risk of not identifying some studies eligible for inclusion. It is possible that we missed relevant studies, although we believe that this is unlikely given our systematic search strategy. Only one reviewer screened titles/abstracts and so may have missed some studies. However, the number of retrieved articles is similar to other searches for social support smoking cessations interventions [18], suggesting that the risk of over-looking studies was minimal. Due to study resource constraints additional systematic searches for articles have not been conducted since the original search in 2014. However, PsychInfo, Ovid Embase and Ovid Medline auto-alerts suggest that no additional studies have been published. The search identified a heterogeneous range of studies (intervention approaches, targets, focus on reduction or cessation, contexts and methodologies), which precluded the ability to see the identified articles as a cohesive group. Further, family members were not treated similarly across studies, with some research positioning relatives as supportive and others as a simultaneous target of smoking behavior change. The heterogeneity and small number of articles also prevented the conduct of a meta-analysis of study findings.

\section{Conclusion}

It is premature to conclude that family-based interventions are not an effective component to cessation programmes. Current evidence suggests that family-based interventions are inadequately theorized. This is in sharp contrast to complex intervention guidelines, which note that using theory is important [48]. Our review indicates that family-based approaches, which rely exclusively on social support or social influence models to aid a quit attempt are missing a trick; future family-based interventions should draw on systemic and relational theories which offer more fine-grained understandings of the mutuality of relational influence, current family context and the genealogy of familial health behaviours. That is, social support theory while having a façade of utility, does not offer a framework for examining the rich current and past influences of familial relationships on health behaviours. Practitioners in primary care have a unique opportunity to make use of social support theories and systemic relational theories where they may have contact with multiple people within one family system.

\section{Additional file}

Additional file 1: Searches conducted. (DOC $167 \mathrm{~kb}$ )

Acknowledgements

Not applicable.

Funding

Not applicable.

Availability of data and materials

Data extraction files are available on request.

Authors' contributions

$\mathrm{GH}$ conceived the study, contributed to the design and conduct of the study and drafted the manuscript. GH, TG, LF, GO contributed to the design and conduct of the study, and drafted the manuscript. RP conducted the searches. All authors read and approved the final manuscript.

\section{Authors' information}

GH (Reader) and TG (senior lecturer) are behavioural scientists adopting family-based approaches to changing health-related behaviours. LF is a family and systemic psychotherapist and Professor of Palliative Care. GO is a senior lecturer in health psychology.

Competing interests

The authors declare that they have no competing interests.

Consent for publication

Not applicable.

Ethics approval and consent to participate Not applicable. 


\section{Author details}

'School of Health Sciences, University of Stirling, Highland Campus, Centre for Health Science, Old Perth Road, Inverness, UK. ${ }^{2}$ School of Medicine, Medical and Biological Sciences Building, University of St Andrews, St Andrews, UK. ${ }^{3}$ Highland Health Sciences Library, University of Stirling, Highland Campus, Centre for Health Science, Inverness, UK. ${ }^{4}$ Australian Catholic University, Canberra, Australia.

\section{Received: 1 December 2015 Accepted: 19 May 2016}

\section{Published online: 24 June 2016}

\section{References}

1. Lim SS, Vos T, Flaxman AD, Danaei G, Shibuya K, Adair-Rohani H, et al. Comparative risk assessment of burden of disease and injury attributable to 67 risk factors and risk factor clusters in 21 regions, 1990-2010: a systematic analysis for the Global Burden of Disease Study 2010. Lancet. 2010;380: 2224-60.

2. World Health Organisation. World Health Organization. Tobacco facts. 2012. http://www.who.int/mediacentre/factsheets/fs339/en/. Accessed 07 Mar 2015.

3. Taylor AE, Howe LD, Heron JE, Ware JJ, Hickman M, Munafa MR. Maternal smoking during pregnancy and offspring smoking initiation: assessing the role of intrauterine exposure. Addiction. 2014;109:1013-21.

4. Leonardi-Bee J, Jere ML, Britton J. Exposure to parental and sibling smoking and the risk of smoking uptake in childhood and adolescence: a systematic review and meta-analysis. Thorax. 2011:6610:847-55.

5. Monden CWS, De Graaf ND, Kraaykamp G. How important are parents and partners for smoking cessation in adulthood? An event history analysis. Prev Med. 2003:36:197-203.

6. Nafstad P, Botten G, Hagen J. Partner's smoking: a major determinant for changes in women's smoking behaviour during and after pregnancy. Public Health. 1996;110:379-85.

7. Pisinger C, Vestbo J, Borch-Johnsen $\mathrm{K}$, Jargensen T. It is possible to help smokers in early motivational stages to quit. The Inter99 study. Prev Med. 2005:40:278-84.

8. Ruge J, Ulbricht S, Schumann A, Rumpf HJ, John U, Meyer C. Intention to quit smoking: is the partner's smoking status associated with the smoker's intention to quit? Int J Behav Med. 2008;15:328-35.

9. Severson $\mathrm{HH}$, Andrews JA, Lichtenstein $\mathrm{E}$, Wall $\mathrm{M}$, Akers L. Reducing maternal smoking and relapse: long-term evaluation of a pediatric intervention. Prev Med. 1997:26:120-30.

10. Lichtenstein E, Glasgow RE, Abrams DB. Social support in smoking cessation: in search of effective interventions. Behav Ther. 1986;17:607-19.

11. Westmaas JL, Bontemps-Jones J, Bauer JE. Social support in smoking cessation: reconciling theory and evidence. Nicotine Tob Res. 2010;12:695-707.

12. Gulliver SB, Hughes JR, Solomon L, Dey AN. An investigation of selfefficacy, partner support and daily stresses as predictors of relapse to smoking in self-quitters. Addiction. 1995:90:767-72.

13. McBride C, Curry SJ, Grothaus LC, Nelson JC. Partner smoking status and pregnant smoker's perceptions of support for and likelihood of smoking cessation. Health Psychol. 1998;17:63-9.

14. Roski J, Schmid LA, Lando HA. Long-term associations of helpful and harmfu spousal behaviors with smoking cessation. Addict Behav. 1996;21:173-85.

15. Rohrbaugh MJ, Shoham V, Trost S, Muramoto M, Cate RM, Leischow S Couple dynamics of change-resistant smoking: toward a family consultation model. Fam Process. 2001:40:15-31.

16. Ford P, Clifford A, Gussy K, Gartner C. A systematic review of peer-support programs for smoking cessation in disadvantaged groups. Int J Environ Res Public Health. 2013;10:5507-22

17. May S, West R. Do social support interventions ("buddy systems") aid smoking cessation? A review. Tob Control. 2000;9:415-22.

18. Park EW, Tudiver FG, Campbell T. Enhancing partner support to improve smoking cessation. Cochrane Database of Syst Rev. 2012;7. Art. No: CD002928; doi: 10.1002/14651858.CD002928.pub3.

19. Setodji CM, Martino SC, Scharf DM, Shadel WG. Friends moderate the effects of pro-smoking media on college students' intentions to smoke. Psychol Addict Behav. 2013;27:265-61.

20. Szabo E, White $V$, Hayman J. Can home smoking restrictions influence adolescents' smoking behaviors if their parents and friends smoke? Addict Behav. 2006;31:2298-303.
21. Committee on Health and Behavior - Research, Practice and Policy, Board of Neuroscience and Behavioral Health, Health Behavior. The interplay of biological, behavioral, and societal influence. Washington: The National Academies Press; 2001

22. Silva C, Smart C, editors. The New Family? London: Sage; 1999.

23. Rook KS. Reciprocity of social exchange and social satisfaction among older women. J Pers Soc Psychol. 1987;52:145-54.

24. Hochschild AR. The unexpected community. Englewood Cliffs: Prentice-Hall; 1987

25. Arling G. The elderly widow and her family, neighbors and friends. J Marriage Fam. 1976:38:757-68.

26. Weiss R. The provisions of social relationships. In: Rubin Z, editor. Doing unto others. Englewood Cliffs: Prentice-Hall; 1974. p. 17-26.

27. Moher D, Liberati A, Tetzlaff J, Altman DG, The PRISMA Group. Preferred reporting items for systematic reviews and meta-analyses: the PRISMA statement. BMJ. 2009. doi:10.1136/bmj.b2535.

28. Higgins JPT, Green S, editors. Cochrane Handbook for Systematic Reviews of Interventions Version 5.1.0 [updated March 2011]. The Cochrane Collaboration, 2011. http://www.cochrane-handbook.org. Accessed 28 Feb 2015.

29. Schulz KF, Altman DG, Moher D, for the CONSORT Group. CONSORT 2010 Statement: updated guidelines for reporting parallel group randomised trials. BMJ. 2010;340:c332

30. Hoffmann TC, Glasziou PP, Boutron I, Milne R, Perera R, Moher D, et al. Better reporting of interventions: template for intervention description and replication (TIDieR) checklist and guide. BMJ. 2014. doi:10.1136/bmj.g1687.

31. Michie S, van Stralen MM, West R. The behaviour change wheel: a new method for characterising and designing behaviour change interventions. Implement Sci. 2011. doi:10.1186/1748-5908-6-42.

32. Michie S, Prestwich A. Are interventions theory-based? Development of a Theory Coding Scheme. Health Psychol. 2010;29:1-8.

33. Centre of Reviews and Dissemination. Systematic Reviews: CRD's guidance for undertaking reviews in health care. York: CRD; 2009.

34. McBride CM, Baucom DH, Peterson BL, Pollak Kl, Palmer C, Westman E, et al Prenatal and postpartum smoking abstinence: a partner-assisted approach. Am J Prev Med. 2004;27:232-8.

35. de Vries H, Bakker M, Dolan Mullen P, van Breukelen G. The effects of smoking cessation counseling by midwives on Dutch pregnant women and their partners. Patient Educ Couns. 2006:63:177-87.

36. Øien T, Storrø O, Jenssen JA, Johnsen R. The impact of a minimal smoking cessation intervention for pregnant women and their partners on perinatal smoking behavior in primary health care: a real-life controlled study. BMC Pub Health. 2008:8:325.

37. Wood DA, Kotseva K, Connolly S, Jennings C, Mead A, Jones J, Holden A, De Bacquer D, Collier T, De Backer G, Faergeman O, EUROACTION Study Group. Nurse-coordinated multidisciplinary, family based cardiovascular disease prevention programme (EUROACTION) for patients with coronary heart disease and asymptomatic individuals at high risk of cardiovascular disease: a paired, cluster-randomised controlled trial. Lancet. 2008:371:199-2012.

38. Hjermann I, Velve Byre K, Holme I, Leren P. Effect of diet and smoking intervention on the incidence of coronary heart disease: report from the Oslo Study Group or a randomized trial in healthy men. Lancet. 1981;12: 1303-10.

39. McIntyre-Kingsolver K, Lichtenstein E, Mermelstein RJ. Spouse training in a multicomponent smoking-cessation program. Behav Ther. 1986:17: 67-74.

40. Patten CA, Hughes CA, Lopez KN, Thomas JL, Brockman TA, Smith CM, et al. Web-based intervention for adolescent nonsmokers to help parents stop smoking: a pilot feasibility study. Addict Behav. 2012;37:85-91.

41. Nyborg KF, Nevid JS. Couples who smoke: a comparison of couples training versus individual training for smoking cessation. Behav Ther. 1986;17:620-5.

42. Georgas J, Berry JW, van der Vijver FJR, Kagitcibasi C, Poortinga YH. (Eds). Families across cultures: A 30 nation psychological study. Cambridge: Cambridge University Press; 2006.

43. Lichtenstein E, Glasgow RE. Smoking cessation: what have we learned over the past decade? J Consult Clin Psychol. 1992;18:63-71.

44. Campbell TL, Patterson JM. The effectiveness of family interventions in the treatment of physical illness. J Marital Fam Ther. 1995:21:545-83.

45. Shoham V, Rohrbaugh MJ, Trost SE, Muramoto M. A family consultation intervention for health-compromised smokers. J Subst Abuse Treat. 2006:31: 395-402. 
46. McDaniel SH, Campbell TL, Hepworth J, Lorenz A. Family-oriented primary care. 2nd ed. New York: Springer; 2005.

47. Schuler TA, Zaider TI, Li Y, Hichenberg S, Masterson M, Kissane D. Typology of perceived family functioning in an American sample of patients with advanced cancer. J Pain Symptom Manage. 2014;48:281-8.

48. Craig P, Dieppe P, Maclntyre S, Michie S, Nazareth I, Petticrew M. Developing and evaluating complex interventions: new guidance. London: Medical Research Council; 2008

Submit your next manuscript to BioMed Central and we will help you at every step:

- We accept pre-submission inquiries

- Our selector tool helps you to find the most relevant journal

- We provide round the clock customer support

- Convenient online submission

- Thorough peer review

- Inclusion in PubMed and all major indexing services

- Maximum visibility for your research

Submit your manuscript at www.biomedcentral.com/submit 